DOI:10.24193/tras.54E.8

Published First Online: 2018/06/29

\section{MEASURING \\ PUBLIC SECTOR INNOVATION}

\section{Sorin Dan ŞANDOR}

\section{Sorin Dan ŞANDOR}

Professor, Department of Public Administration and Management, Faculty of Political, Administrative and Communication Sciences, Babeş-Bolyai University, Cluj-Napoca, Romania

Tel.: 0040-264-431.361

E-mail: sandor@fspac.ro

\title{
Abstract
}

The goal of this paper is to present and discuss the difficulties in defining and measuring innovation. The large number of existing definitions is yet failing to make the necessary distinction between innovation and other related concepts. There is no agreement about the most relevant dimensions of innovation and, without a proper definition of innovation, measurement is more difficult.

Several methods and attempts of measurement - Awards and Surveys - are identifying different meanings and characteristics of innovation. A more in-depth analysis of a pilot exercise in measuring innovation, namely the European Public Sector Innovation Scoreboard 2013, is done in order to examine its methodology and the validity of its findings for the specific case of Romania.

The need for an innovative public sector is generally recognized, and present measurement attempts are actually overestimating the level of innovation. In order to assess this correctly a clearer and narrower definition is needed, the framework of the innovative process needs to be further investigated and research designs have to be improved.

Keywords: innovation, measurement, European Public Sector Innovation Scoreboard. 


\section{Defining innovation}

'If you can't measure it, you can't manage it' is a widely used but incomplete quote often attributed to Deming or to Drucker, the original source being - 'It is wrong to suppose that if you can't measure it, you can't manage it' (Deming, 1994, p. 35). Osborne and Gaebler (1992) use a similar catch phrase in order to emphasize measurement: 'What gets measured gets done'. Starting from the 1990s, performance indicators became more and more popular and in more and more fields of activity. Governments around the world are widely using measurement systems for innovation thinking that measuring innovation is a must in order to manage it.

The first step of any measurement process is defining the concept that has to be measured. Innovation was explored since Schumpeter saw it as a central source for economic development more than a hundred years ago (1911). In Schumpeter's view innovation was the commercial application of a new idea. Only by the end of the 1980s the first attempts to define innovation in order to be measured were taken. The OECD Working Party of National Experts on Science and Technology Indicators (NESTI) codified innovation in what is known as the Oslo Manual. The first definition of innovation (OECD, 1992) was strictly about technological innovation and comprised two components: product innovation and process innovation. Only the third version of the manual was dedicated to all kinds of innovation (not only technological) and the definition became 'An innovation is the implementation of a new or significantly improved product (good or a service), or process, a new marketing method, or a new organization method in business practices, workplace organization or external relations' (OECD/Eurostat, 2005, p. 46). Two more components were added: marketing and organization methods as a reflection of the growing importance of services in the global economy. All the components mentioned by the Oslo Manual are market-oriented - and as Gault (2010, p. 155) considers, public sector innovation measurement and analysis has to be quite different from that in the private sector. Kattel et al. (2013) consider that starting from 2000 the literature on public sector innovation intended to move away from the private sector approach but this has been done mostly by adapting it to the public sector realities.

A definition should present the main characteristics of a phenomenon while clearly distinguishing it from other similar phenomena. We identified 11 main characteristics that have to be addressed when defining innovation.

1. Innovation - is it a Process or a Result? In other words, should we measure the process or its results? Both are of interest, but we should not mix them. NESTA (Hughes, Moore and Kataria, 2011) approach is clearly process-oriented: it measures wider sector conditions, innovation capability, innovation activity and impact. Other innovation surveys are taking similar approaches. Innovation in the public sector can be defined as the process of generating new ideas and implementing them to create value for society, covering new or improved processes (internal focus) and services (external focus) (European Commission, 2013). Also, innovation can be defined as a change (Hartley, 2005). If we understand innova- 
tion as the results of the innovation process only the outputs of the innovation activity would have been of interest.

2. Size - are we discussing small, incremental improvements or are we searching for evolutionary steps? Christensen (1997) advocated for radical or disruptive innovations (those with a great impact) - but, instead, more general approaches were preferred - as in European Commission (2011) - 'any significant improvement' will do.

3. Novelty - New idea vs. Existing idea. How new should an idea be in order to qualify as an innovation? The Oslo Manual, first edition, (OECD, 1992, p. 41) classified novelty as: new to the firm, the country or the market, or the world. The first two are used in defining innovation, as the last might bring an overlap with invention, but the difference between being new to the firm and being new to the country (market or sector) is a significant one. Lynn (1997) emphasizes that innovation should be original. Innovation is defined by Albury (2005) as 'creation and implementation', and by the European Commission (2013) as generation and implementation of new ideas - creation and generation implying a high degree of novelty. Definitions that equate innovation with change are not usually specifying the degree of novelty. Other definitions stick with new to the firm, like West and Farr (1990): 'new to the relevant unit of adoption'.

4. Adoption - Adaptation or Imitation? If an innovation can be new only to the institution, being already introduced elsewhere, are we discussing about adaptation or imitation? De Lancer Julnes and Gibson (2016) use in their definition the term adoption, West and Farr (1990) are talking about introduction and application, European Commission (2013) mentions implementation. We do not have a clear answer - is imitation a form of innovation?

5. Intentionality - Intentional or Unintentional? Should innovation be intentional or it may just happen? West and Farr (1990) in their definition stress the intentional character of innovation. In some definitions a certain amount of intentionality is implied, especially when mentioning generation or creation. In other definitions there is no hint of intentionality. Innovation as a process supposes intentionality. Many inventions and innovations were adopted against the will of the organizations.

6. Origin - Mandated vs. Voluntary. This is close to the previous characteristic but it is specific to public organizations in which change can be imposed from the outside through laws and regulations. If a specific law is requiring that an institution has to adopt a specific new process can we call that organization as being innovative?

7. Scope - Product, Service, Policy or Process? The Oslo Manual had in its first edition only the first two and added other two components later (marketing and organization methods). Is this too much already? Galindo-Rueda and Van Cruysen (2016) are reporting about confusions made by managers trying to distinguish between components (especially regarding organizational innovation). Should we go further than that? Is a definition like: 'Innovation is about the relationship between service providers and their users' (Hartley, 2005, p. 27) fitting these components or is it adding new ones? What about social innovation (Gault, 2010), or governance 
innovation (Hartley, 2005) or European Commission's (2013) innovation through initiatives that foster innovation elsewhere in society.

8. Type-Radical, Architectural, Modular or Incremental? Henderson and Clark (1990) distinguish between the types of innovation according to two different criteria - if the system or the linkages in the system and/or the components (the core concepts) have changed. A radical innovation changes both the system and the components, an architectural innovation addresses only the system, a modular innovation the components and an incremental innovation does not change any of them. Incremental innovation may not be considered as an innovation by many definitions.

9. Improvement - Do innovations have to be successful? West and Farr (1990) consider that innovations have to be 'designed to significantly benefit the individual, the group or wider society' - so intention might be enough. Other definitions are asking for some degree of success. European Commission (2013) sees innovation as creating value for society, Innobarometer (2011) demands significant improvements. On the other hand, Hartley (2005, p. 31) considers that you can have 'innovation but no improvement', in which we can find innovations unsuccessful or not valuable.

10.Value - How can we define public value? How can we measure it? Cole and Parston (2006), and Bason (2010) found that public value can be found as outcomes, services, productivity or democracy. The Australian framework for measuring public sector innovation lists as outcomes societal and environmental benefits, quality, efficiency and productivity, employee satisfaction, benefits for users, trust and legitimacy. As we can see, the list may be extremely long without being exhaustive. There are only few indications on how to measure multidimensional impacts of innovation (Kattel et al., 2013).

11.Sustainability - do one-time initiatives count? All the definitions consider that innovation is a tool to improve the regular services and processes so it has to have a long-lasting effect. Moore, Sparrow and Spelman (1997) claim that innovation should be 'durable enough to appreciably affect the operations or character of the organization'. What if some organization finds a new way to solve a unique situation - is this innovation or not?

12.Diffusion or Dissemination? Those two terms are often used in an interchangeable way. Still, dissemination is indicating a more active process and it is deemed as an important part of the innovation process. NESTA (Hughes, Moore and Kataria, 2011) is including dissemination as an innovation activity. In the public sector it is important that successful innovations are transferred to other organizations concerned, but is really dissemination a part of the innovation process? (Is an organization more innovative if it does more dissemination?)

Such characteristics have to be carefully pondered before defining innovation. The biggest concern is of confounding innovation with change. De Lancer Julnes and Gibson $(2016$, p. 3) define innovation as 'adoption and implementation of change'. Such a definition is too general - any change might be considered an innovation. 


\section{Assessing innovation in the public sector}

We may distinguish four different ways in assessing innovation:

1. Research on specific innovations through case studies;

2. Best practices or Innovation Awards;

3. Managers' surveys asking about the use of some innovative practices and technologies;

4. Innovation surveys are measuring the innovation state of an entire sector/country, asking about a wide range or all innovation activities and types of innovations implemented over a defined time period. As Arundel, Bloch and Ferguson (2016) remarked, these are influenced by the Oslo Manual and the Community Innovation Surveys based on the Manual. These are subject-based, dedicated to the measurement of the innovation state.

The first method is extremely useful when trying to assess the merits of a specific innovation, but is not that useful in trying to compare different innovations (as case studies are reflecting the particular nature of each innovation) and aggregating data in order to assess the degree of innovation in an industry or sector is impossible due to the small number of cases and to their specificity.

Innovation Awards are more useful for a larger number of cases as they have to use the same criteria in assessing different innovations in order to identify the best practices. The scientific value of such events is not very high as these awards are mostly celebrations or dissemination vehicles and the data is self-reported by the candidates. Still the criteria used are instructive.

The Innovations in American Government Award organized by the Ash Center for Democratic Governance at Harvard University is using the following criteria:

- Novelty, the degree to which the program or initiative demonstrates a leap in creativity;

- Effectiveness, the degree to which the program or initiative has achieved tangible results;

- Significance, the degree to which the program or initiative successfully addresses an important problem of public concern;

- Transferability, the degree to which the program or initiative, or aspects of it, show promise of inspiring successful replication by other governmental entities.

We can see that innovation has to have a high degree of novelty, has to be successful, to address an important issue and to be transferable in order to get the award.

A similar initiative took place in Romania, organized by the National Agency for Public Service. Ten criteria with different weights are used.

We can see that novelty is less important than diffusion and as important as presentation. Also, the way in which it was done (as in partnership and with citizens' involvement) is highly valued. There is no indication about the way in which effectiveness, efficiency and impact are measured (or if and how the self-reported data is checked). 
Table 1: National Agency for Public Service Best Practices Award

\begin{tabular}{lc}
\hline \multicolumn{1}{c}{ Criteria } & Weight (\%) \\
\hline Novelty & 5 \\
Presentation & 5 \\
Effectiveness & 20 \\
Efficiency & 17.5 \\
Administrative simplification & 7.5 \\
Replicability and diffusion & 17.5 \\
Partnerships & 10 \\
Impact & 5 \\
Sustainability & 10 \\
Citizens involvement & 7.5 \\
\hline
\end{tabular}

Source: National Agency for Public Service (n.d.)

Managers' surveys asking about the use of some innovative practices are used in order to find out if and how some innovations are used in the sector (e.g., a survey on the use of quality management practices). These might be used to shed some light if, to what extent and how some practices are used. Sometimes innovation is seen in such a research as part of a larger picture. United Nations (2015) is assessing the state of e-government, and in the process is also checking for innovative coordination processes and mechanisms for service delivery and citizen engagement and empowerment.

Innovation Surveys for measuring innovation within businesses are becoming more and more popular in the public sector. Arundel, Bloch and Ferguson (2016) list nine different studies done in the last nine years in twelve different countries and one of them in all EU countries. Some of them will be presented in the following section.

Hughes, Moore and Kataria (2011) are presenting NESTA - the public sector innovation indices (UK). Innovation is defined according to the Oslo Manual. NESTA is proposing an innovation index for public sector organizations, based on a scorecard approach using the innovation framework below.

Table 2: NESTA - the public sector innovation indices

\begin{tabular}{|c|c|c|c|}
\hline Impact & $\begin{array}{l}\text { Innovation } \\
\text { Activity }\end{array}$ & $\begin{array}{l}\text { Innovation } \\
\text { Capability }\end{array}$ & $\begin{array}{l}\text { Wider Sector Conditions } \\
\text { for Innovation }\end{array}$ \\
\hline $\begin{array}{l}\text { Improvement in organizational } \\
\text { key performance indicators }\end{array}$ & Accessing new ideas & Leadership and culture & Incentives \\
\hline $\begin{array}{l}\text { Improvement } \\
\text { in service evaluation }\end{array}$ & $\begin{array}{l}\text { Selecting and developing } \\
\text { ideas }\end{array}$ & Management of innovation & Autonomy \\
\hline Improvement in efficiency & Implementing ideas & $\begin{array}{l}\text { Organizational enablers } \\
\text { of innovation }\end{array}$ & Leadership and culture \\
\hline Improvement context & Diffusing what works & & Enablers \\
\hline
\end{tabular}

Source: Hughes, Moore and Kataria (2011)

The pilot survey showed a high degree of innovation in both sectors surveyed health and local government. 
The Australian Public Sector Innovation Indicators (APSII) uses a similar definition and a different framework (Australian Government, 2011).

Table 3: The Australian Public Sector Innovation Indicators (APSII) Framework

\begin{tabular}{|c|c|c|c|}
\hline Inputs & Process & Outputs & Outcomes \\
\hline Investment in innovation & Diffusion of innovation & $\begin{array}{l}\text { Innovation (activities } \\
\text { and implementation) }\end{array}$ & $\begin{array}{l}\text { Societal and } \\
\text { environmental impacts }\end{array}$ \\
\hline $\begin{array}{l}\text { Human resources and } \\
\text { skills for innovation }\end{array}$ & Innovation collaborations & Types of innovation & $\begin{array}{l}\text { Quality, efficiency } \\
\text { and productivity }\end{array}$ \\
\hline $\begin{array}{l}\text { Staff attitudes and } \\
\text { attributes for innovation }\end{array}$ & $\begin{array}{l}\text { Innovation management } \\
\text { practice }\end{array}$ & Innovation novelty & $\begin{array}{l}\text { Improved employee } \\
\text { satisfaction }\end{array}$ \\
\hline Sources of innovation & $\begin{array}{l}\text { Innovation culture } \\
\text { and leadership }\end{array}$ & Innovation intensity & Benefits for users \\
\hline $\begin{array}{l}\text { Technological infrastructure } \\
\text { for innovation }\end{array}$ & Innovation strategy & Intangible outputs & $\begin{array}{l}\text { Other intangible effects } \\
\text { (e.g. trust and legitimacy) }\end{array}$ \\
\hline \multicolumn{4}{|c|}{ Environmental conditions } \\
\hline $\begin{array}{l}\text { User demand and supplier } \\
\text { capacity }\end{array}$ & $\begin{array}{l}\text { Wider public sector } \\
\text { leadership and culture }\end{array}$ & $\begin{array}{l}\text { Political and } \\
\text { legislative factors }\end{array}$ & $\begin{array}{l}\text { Other enablers/barriers to } \\
\text { innovation (e.g. research } \\
\text { basis, skills shortage) }\end{array}$ \\
\hline
\end{tabular}

Source: Australian Government (2011)

While impact and outcomes are more or less similar, APSII has as outputs different characteristics of innovation and as process and inputs we have items related in NESTA to capability. A total of $91.3 \%$ of institutions introduced some type of innovation over a two year period, mostly (85\%) regarding process innovation (Australian Government, 2013).

A similar survey is EU's Innobarometer. Data from this research, but also from other sources of data (Eurostat, World Bank, World Economic Forum, United Nations or OECD), are incorporated into the European Public Sector Innovation Scoreboard.

\section{European Public Sector Innovation Scoreboard 2013}

Innovation is regarded as 'any significant improvement in operational practices (either in the product/service range or in support structures)' (European Commission, 2011, p. 13). The framework used by EPSIS is simpler than NESTA or APSII - enablers make activities possible and these activities generate outputs.

Some of the criteria might be debatable. 3.2. and 3.3 are not innovations made by institutions but innovations 'through' the public sector (European Commission, 2013). Quality of public services and especially the use of e-government are seen both as an enabler and as an innovation.

The major findings were (European Commission, 2011, p. 8):

- At EU level, two-thirds of public administration institutions introduced a new or significantly improved service in the last 3 years before the survey;

- The likelihood of service innovation increased linearly with the size of the institutions. State institutions were just as likely as independent ones to introduce innovations; 
Table 4: EPSIS Framework

\begin{tabular}{|c|c|c|}
\hline Enablers & Activities & Outputs \\
\hline 1.1 HUMAN RESOURCES & 2.1 CAPACITIES & 3.1 INNOVATORS \\
\hline $\begin{array}{l}\text { 1.1.1 Employment share } \\
\text { of 'creative occupations' }\end{array}$ & $\begin{array}{l}\text { 2.1.1 Share of service innovators } \\
\text { that innovate in-house }\end{array}$ & $\begin{array}{l}\text { 3.1.1 Share of organizations in public admi- } \\
\text { nistration with services, communication, } \\
\text { process or organizational innovations }\end{array}$ \\
\hline $\begin{array}{l}\text { 1.1.2 Share of employees } \\
\text { in public administration } \\
\text { with a university degree }\end{array}$ & $\begin{array}{l}2.1 .2 \text { Share of process innovators } \\
\text { that innovate in-house }\end{array}$ & $\begin{array}{l}\text { 3.1.2 Share of 'New' services out } \\
\text { of all services innovations }\end{array}$ \\
\hline $\begin{array}{l}\text { 1.2 QUALITY OF PUBLIC } \\
\text { SERVICES }\end{array}$ & 2.2 DRIVERS AND BARRIERS & 3.1.3 Public sector productivity \\
\hline 1.2.1 Government effectiveness & $\begin{array}{l}2.2 .1 \text { Importance of internal } \\
\text { barriers to innovation }\end{array}$ & $\begin{array}{l}\text { 3.2 EFFECTS ON BUSINESS } \\
\text { PERFORMANCE }\end{array}$ \\
\hline 1.2.2 Regulatory quality & $\begin{array}{l}2.2 .2 \text { Importance of external } \\
\text { barriers to innovation }\end{array}$ & $\begin{array}{l}3.2 .1 \text { Improvements in public services } \\
\text { for business }\end{array}$ \\
\hline $\begin{array}{l}1.2 .3 \text { Increased efficiency } \\
\text { of government services } \\
\text { due to the use of ICT }\end{array}$ & $\begin{array}{l}\text { 2.2.3 Active management } \\
\text { involvement in innovation }\end{array}$ & $\begin{array}{l}3.2 .2 \text { Impact of innovative public services } \\
\text { on business }\end{array}$ \\
\hline $\begin{array}{l}\text { 1.2.4 Online availability } \\
\text { of public services }\end{array}$ & $\begin{array}{l}2.2 .4 \text { Importance of external } \\
\text { knowledge }\end{array}$ & 3.3 GOVERNMENT PROCUREMENT \\
\hline \multirow[t]{3}{*}{$\begin{array}{l}\text { 1.2.5 E-government } \\
\text { development index (EGDI) }\end{array}$} & $\begin{array}{l}2.2 .5 \text { Share of employees } \\
\text { involved in groups that meet } \\
\text { regularly to develop innovations }\end{array}$ & $\begin{array}{l}\text { 3.3.1 Government procurement as a driver } \\
\text { of business innovation }\end{array}$ \\
\hline & & $\begin{array}{l}\text { 3.3.2 Government procurement } \\
\text { of advanced technology products }\end{array}$ \\
\hline & & $\begin{array}{l}\text { 3.3.3 Importance of innovation } \\
\text { in procurement }\end{array}$ \\
\hline
\end{tabular}

Source: European Commission (2011)

- The single most important driver of innovation in the public sector was the introduction of new laws and regulations, followed by new policy priorities and mandated implementations of an online service provision;

- Budget cuts are triggering innovation;

- Major barriers are lack of resources and rigid regulatory framework;

- Major sources of innovation were: ideas from staff, ideas from management and input from clients or users;

- Top-down approach of innovation or innovation support is prevalent;

- Positive effects of innovation were identified as: improved user access to information, improved user satisfaction, more targeted services, a faster delivery of services, simplified administration, improved working conditions or employee satisfaction and cost reductions;

- New technologies, higher demand from citizens, new policy priorities and new regulations are expected to improve the organizational innovation ability.

The results for each country are represented in Figure 1. Green light on one indicator means that one country is in the top third scores, yellow light that it is in the second third and red light in the bottom third. We can see that out of the 23 criteria 


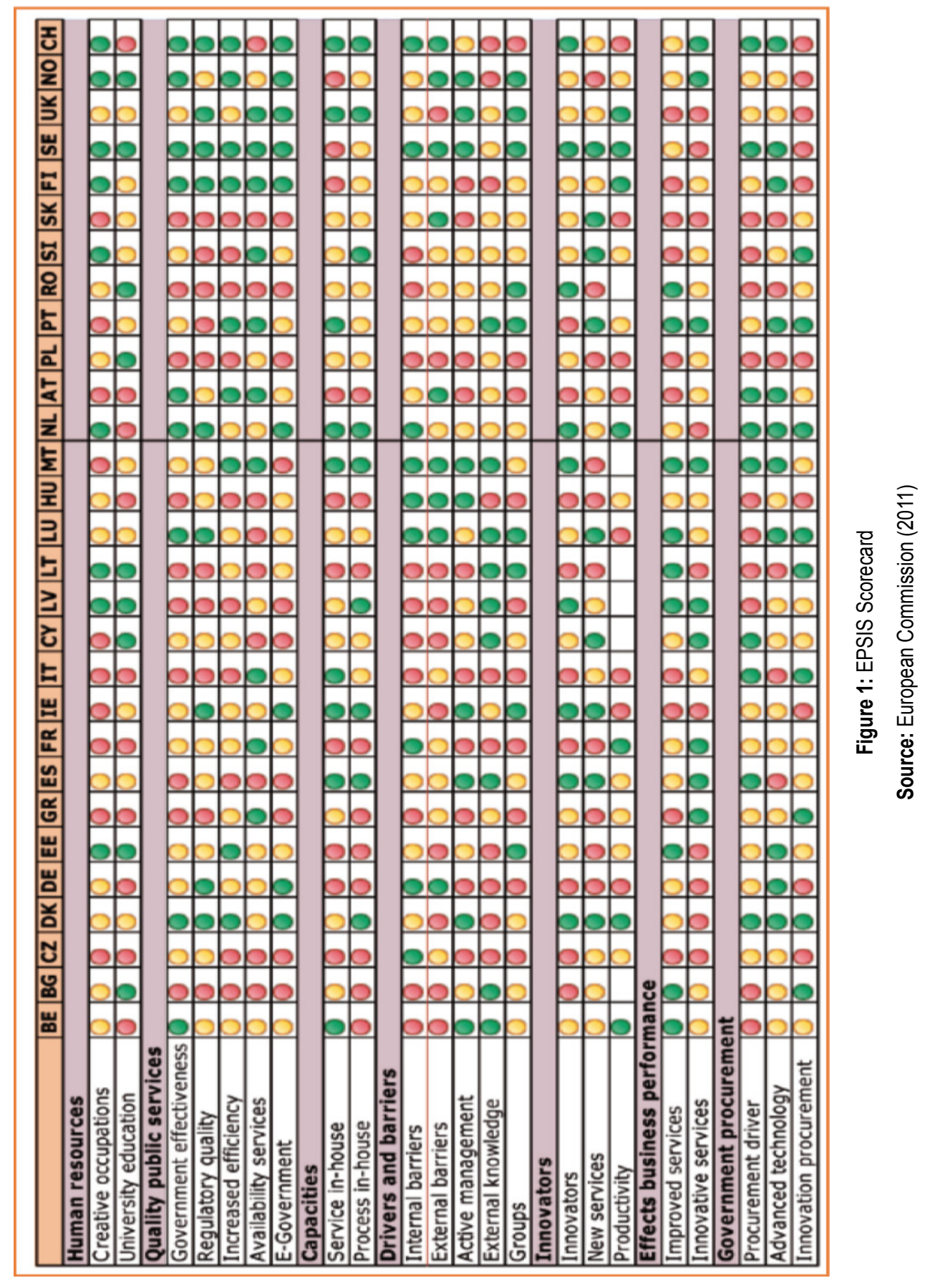


Romania has four green lights (in university education, share of employees involved in groups that meet regularly to develop innovations, innovators and improved services), eight yellow lights (especially in capacity and drivers or barriers) and eleven red lights (for the quality of public services - data which is not self-reported in the Innobarometer, internal barriers, new services and procurement). The image is not of a particularly good performance regarding innovation. Only $9.8 \%$ of the institutions could have been classified as leading innovators (EU27 - 16.9\%) and 36.3\% of the institutions (EU27 - 33.7\%) are not innovators.

There are still some intriguing findings regarding Romania, in which the national figures are above the EU27 average:

1. The EU27 share of in-house process innovators is quite high at $76 \%$. For small and medium enterprises the EU27 percentage is at 30.3\% (ProInno Europe, 2011). Romania has a greater percentage $-82 \%$.

2. Management is active in promoting innovation - in Romania the percentage of institutions where this is happening is at $46 \%$ (EU27 - 41\%).

3. In $30 \%$ of the Romanian public institutions staff meets regularly to develop innovations (EU27-22\%).

4. The percentage of Romanian public administrations that innovate in services, communication, process or organizational matters is $93 \%$ (EU27 - 90\%).

5. In Romania, innovation has almost only positive effects $-94.8 \%$, (EU27 - 93.8\%), little negative effects $-15.6 \%$ (EU27 - 30.3\%), mainly costs.

6. New or significantly improved services (out of all innovations) in Romania $17 \%$ (EU27-27\%).

7. Improvement in public services for business: in Romania - 32\% (EU27 - 20\%). But the impact of innovative public services on businesses is reported only by $12 \%$ in Romania (EU27 - 15\%).

These findings appear when we have self-reported data - which might bring a doubt about the results.

\section{Conclusions}

Public administration seems to be a highly innovative sector. The findings are showing us that:

- Most of the public institutions are innovating;

- In-house innovation is flourishing;

- Management actively promotes innovation and a large number of employees are involved in innovation;

- The positive effects of innovation are overwhelming compared to negative effects.

Such results seem too good to be true. The public sector is not a laggard sector but neither a top Research and Development company (considering its attributions). Sev- 
eral possible methodological flaws might affect the quality of the findings:

- Poor definition of innovation and of criteria:

- Any change can be considered innovation - the formulation 'any significant new or improved service' is allowing people to report any change as a significant improvement;

- Means or tools are confounded with goals and further with success (e-government or administrative simplification are just two examples);

- Change in the laws and regulations (which we saw that it is the main source of innovation) is actually mandated innovation; when it comes with specific indications about the way in which the job has to be done and public institutions are just applying the law, we are not discussing about innovation;

- Measuring process indicators does not measure outcomes. Like in the case of measuring university education (input), it says nothing about innovation; more than that, in many cases, to have a university education is a condition for entering most public service jobs.

- The design of the research itself may be an issue - we have institutions as cases. In some institutions there might be more than one innovation. That's why bigger institutions seem to be more innovative. When discussing about more than one innovation subjects will have some difficulty in answering.

- There is little measurement of the public value created - we have questions asking for some possible effects, but this is primarily the subjective opinion of the respondents. There are few user satisfaction surveys made on a regular basis in order to assess an increase in user satisfaction. Also, the phrasing of the questions is actually adding to the effects: 'Have any of your new or significantly improved processes or organizational methods [...], had a major positive effect by...' - if several innovations were made in an organization, with different effects, we may find more positive effects. Arundel, Bloch and Ferguson (2016) consider that measuring outcomes works better for single innovations and not very well for multiple innovations.

- The use of self-administered questionnaire. Self-reporting is usually prone to inflating the results, especially in areas in which the respondents are more personally involved. Questionnaires addressed to an institution will rarely indicate some problems in its functioning and, even less likely, will indicate that there is a problem with management.

The main purpose of the survey seems to confirm the highly innovative status of the public sector. It may be one of the situations in which 'the measures themselves are easily distorted to suit reporting purposes' (Seddon, 2013, p. 71). In the end, we might have found that the public sector is a changing one, but not necessarily an innovative one.

While the innovative state of the public sector might be of concern we should be aware that the public sector is quite heterogeneous. Innovation in public education is different from the one in health; innovation in local public administration is also 
different from the one in central administration. Treating the entire public sector as a monolith is not methodologically sound.

While the use of innovation frameworks is not a problem per se, adding inputs with outcomes in scorecards surely is. More elaborate frameworks should be build and the relationships between inputs, enablers, activities, outputs and outcomes should be carefully analyzed - something that is missing in many of the studies done until now.

A clear definition of innovation should clearly distinguish innovation from change, especially when we have mandated change (e.g. mandated by laws and regulations). More information is needed about the novelty, size and type of innovations. Measurement of outcomes is difficult, but we need to know if it is based on subjective opinions or on objective data.

In terms of design while we can start with institutions (discuss about inputs or enablers at organizational level) we might try to discuss about each innovation - in order to find specific information about each major innovation that is happening in the organization.

It is known, at least since 2011 (Galindo-Rueda and van Cruysen, 2016), that cognitive testing of the questions of the OECD Community Innovation Surveys (a major source of inspiration for NESTA, APSII or Innobarometer) has shown that many concepts are not properly operationalized and measured and, yet, no improvement was made. Still, such efforts should continue and the recommendations should be applied.

\section{References:}

1. Albury, D., 'Fostering Innovation in Public Services', 2005, Public Money and Management, vol. 25, no. 1, pp. 51-56.

2. Arundel, A., Bloch, C. and Ferguson, B., 'Measuring Innovation in the Public Sector', OECD, [Online] available at https://www.oecd.org/sti/087\%20-\%20ARUNDEL\%20 BLOCH\%20Methodologies\%20for\%20measuring\%20innovation\%20in\%20the $\% 20$ public\%20sector.pdf, accessed on November 3, 2016.

3. Australian Government, Department of Innovation, Industry, Science and Research, 'Measuring Innovation in the Public Sector: A Literature Review', The Australian Public Sector Innovation Indicators (APSII) Project, 2011.

4. Australian Government, Department of Innovation, Industry, Science and Research, 2013, 'Summary of Key Findings from the Australian Public Sector Innovation Indicators (APSII) Project', [Online] available at https://industry.gov.au/innovation/publicsectorinnovation/Documents/Summary-of-Key-Findings.pdf, accessed on November 2, 2016.

5. Bason, C., Leading Public Sector Innovation: Co-creating for a Better Society, Bristol: University of Bristol Policy Press, 2010.

6. Christensen, C.M., The Innovators Dilemma: When New Technologies Cause Great Firms to Fail, Boston: Harvard University Press, 1997.

7. Cole, M. and Parston, G., Unlocking Public Value: A New Model for Achieving High Performance in Public Service Organizations, New Jersey: John Wiley \& Sons, 2006.

8. De Lancer Julnes, P. and Gibson, E., (eds.), Innovation in the Public and Non-profit Sector: A Public Solutions Handbook, London: Routledge, 2016. 
9. Deming, W.E., The New Economics for Industry, Government, Education, $2^{\text {nd }}$ edition, Boston: The MIT Press, 1994.

10. European Commission, 'European Public Sector Innovation Scoreboard 2013 - A Pilot Exercise', [Online] available at http://ec.europa.eu/enterprise/policies/innovation/files/ epsis-2013_en.pdf, accessed on November 3, 2016.

11. European Commission, 'Innobarometer 2010: Analytical Report on Innovation in Public Administration (Flash Eurobarometer 305)', Brussels: DG Enterprise, 2011.

12. Galindo-Rueda, F. and Van Cruysen, A., 'Testing Innovation Survey Concepts, Definitions and Questions: Findings From Cognitive Interviews With Business Managers', Paris: OECD Publications, 2016.

13. Gault, F., Innovation Strategies for a Global Economy. Development, Implementation, Measurement and Management, Cheltenham: Edward Elgar Publishing, 2010.

14. Hartley, J., 'Innovation in Governance and Public Services: Past and Present', 2005, Public Money E Management, vol. 25, no. 1, pp. 27-34.

15. Henderson, R.M. and Clark, K.B., 'Architectural Innovation: The Reconfiguration of Existing Product Technologies and the Failure of Established Firms', 1990, Administrative Science Quarterly, vol. 1, no. 35, pp. 9-30.

16. Hughes, A., Moore, K. and Kataria, N., 'Innovation in Public Sector Organisations: A Pilot Survey for Measuring Innovation across the Public Sector', NESTA Index report, 2011.

17. Kattel, R., Cepilovs, A., Drechsler, W., Kalvet, T., Lember, V. and Tõnurist, P., 'Can We Measure Public Sector Innovation? A Literature Review', LIPSE Project paper, 2013.

18. Lynn, L., 'Innovation and the Public Interest. Insights from the Private Sector', in Altshuler, A. and Behn, R.D., (eds.), Innovation in American Government. Challenges, Opportunities, and Dilemmas, Washington, D.C.: Brookings Institution, 1997, pp. 83-103.

19. Moore, M.H., Sparrow, M.K. and Spelman, W., 'Innovation in Policing: From Production Line to Jobs Shops', in Altshuler, A. and Behn, R.D., (eds.), Innovation in American Government, Washington, D.C.: Brookings Institution, 1997, pp. 274-298.

20. OECD, Proposed Guidelines for Collecting and Interpreting Innovation Data, Paris: OECD Publishing, 1992.

21. OECD/Eurostat, Oslo Manual: Guidelines for Collecting and Interpreting Innovation Data, Paris: OECD and Eurostat, 2005.

22. Osborne, D. and Gaebler, T., Reinventing Government: How the Entrepreneurial Spirit is Transforming the Public Sector, Addison-Wesley, 1992.

23. ProInno Europe, 'Innovation Union Scoreboard 2010 The Innovation Union's Performance Scoreboard for Research and Innovation', Maastricht Economic and Social Research and Training Centre on Innovation and Technology, 2011.

24. Schumpeter, J., Theorie der Wirtschaftlichen Entwicklung, Berlin: Dunkler \& Humblot, 1911.

25. Seddon, J., Freedom from Command and Control: Rethinking Management for Lean Service, New York: Productivity Press, 2005.

26. United Nations, 'United Nations E-Government Survey 2014. E-Government for The Future We Want', Washington, D.C.: United Nations Department of Economic and Social Affairs, 2015.

27. West, M.A. and Farr, J.L., 'Innovation at Work', in West, M.A. and Farr, J.L., (eds.), Innovation and Creativity at Work: Psychological and Organizational Strategies, Chichester: Wiley, 1990, pp. 3-13. 